\title{
The XIII International Research and Practice Conference "Ukrainian School of Mining Engineering" as a step to the new direction of innovative technologies and intelligent systems in the mining industry
}

\author{
Volodymyr Bondarenko ${ }^{1 *}$, Iryna Kovalevska ${ }^{1}$, Roman Lysenko ${ }^{1}$, and Olha Malova ${ }^{1}$ \\ ${ }^{1}$ Dnipro University of Technology, Department of Underground Mining, 19 Yavornytskoho Ave., \\ 49005 Dnipro, Ukraine
}

\begin{abstract}
For the thirteenth time International Research and Practice Conference "Ukrainian School of Mining Engineering" has made an important contribution to the mining industry, science and education, expanding the boundaries of interaction between representatives of science and practicing industry experts, opening up new opportunities for the exchange of experience, solving the most acute problems, presenting a new vision of the future of mining sector and industrial development not only in Ukraine, but also all over the world. This year the conference is mostly dedicated to the new 4.0 level of the industry and had the main topic of "Innovative technologies and intelligent systems in mining". Also, the following problems were not disregarded such as major mining trends, mining mechanical engineering, alternative energy sources, stoping and tunneling equipment, mine workings maintaining and supporting, mineral enrichment, crisis management, safety of mining, sanitation, labor protection, and etc. The results of the conference once again proved that only the community created over the years, where a collision of sciences and various practicing schools takes place, is able to bring the most advanced and innovative ideas to life, laying the foundation for future achievements of the mining industry.
\end{abstract}

\section{Introduction}

The first International Research and Practice Conference "Ukrainian School of Mining Engineering" dates back to 2007, when it was called the "School of Underground Mining" $[1-3]$. Over the years, the field of mining has grown and developed, and with this progress, the conference has evolved too. It was becoming tight to stay within the framework of the topic of minerals underground mining. More and more reports were devoted to various directions of mining engineering. That is how in 2018, our conference finally evolved and reached a new level [4], but still it remains true to its traditions and constantly growing community.

\footnotetext{
* Corresponding author:
} 
"We are founders of informational scientific and practical "School of Underground Mining”, open the it in early 2007. We wish you success, successful initiatives, financial well-being, good health and, of course, simple happiness!

School (lat. Schola from the Greek. Schole) is the system of education, skill, gained experience; direction in science related by basic unity of views, community or common principles and methods.

By creating the "School of Underground Mining", we want with you to consolidate conservation efforts and develop new research areas, good traditions, and help to maintain the status of miners in a decent society.

The volume of minerals, which is extracted by underground mining, at the beginning of the third millennium have reached the maximum values in human history and continue to grow.

Solid natural resources extraction (coal, iron, manganese, titanium, uranium, etc.) shows a high degree of the mechanization, concentration of mining operations and intensification of miners labor.

Today's high-tech equipment is at odds with traditional technologies. The safety of mining operations is reduced and there is virtually no reserve to increase production.

Thus, we can talk about the onset of the nearest future crisis in underground mining of solid minerals. We need fundamentally new technologies, such as desert extraction, mining without the constant presence of people in stoping faces, underground gasification of coal, robotization of production processes, streaming technologies of a new technical level and much more.

It is difficult to overestimate the importance of scientific conferences, symposia, forums, scientific and technical exhibitions, which were successfully conducted and will be carried out. However, in this age of information technology it is not enough. For the rapid acquisition of new knowledge, the exchange of experience, the coordination and integration of scientific knowledge, requires a constantly renewable source of information, and thus, we hope, will become our informational scientific and practical "School of underground mining ".

With deep respect to you,

V. Bondarenko, V. Buzylo, O. Kuzmenko, I. Kovalevska"

With these words [5], the founding professors laid the foundation for the International Research and Practical Conference "School of Underground Mining", which became part of the multifaceted scientific life of Ukraine and the world. But time is flowing so fast that already in September 2019, we conducted our thirteenth "Ukrainian School of Mining Engineering". During this period many interesting events have taken place in our conference, geography has changed and many representatives and friends have appeared.

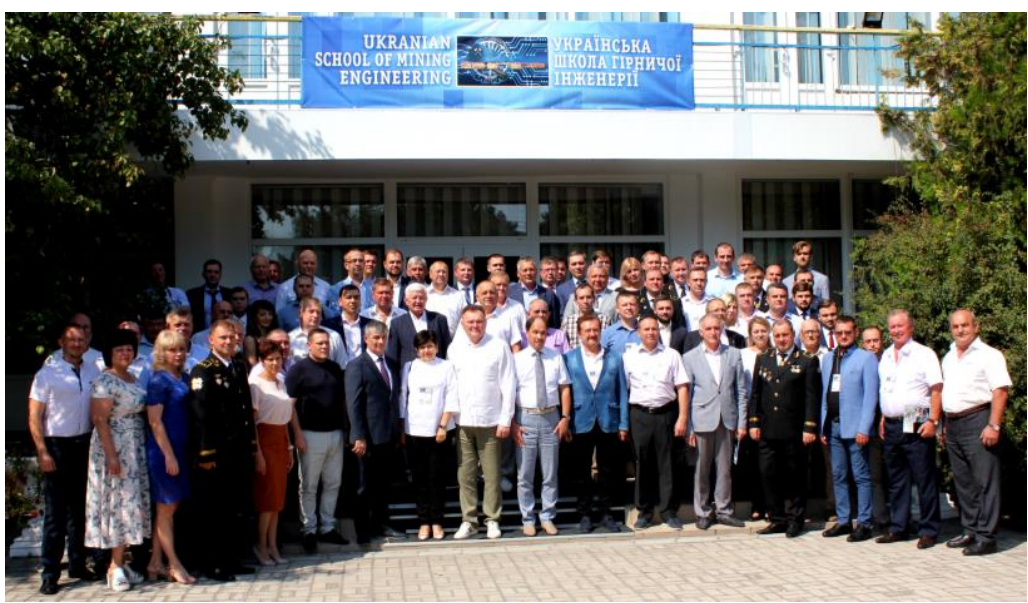

Fig. 1. Participants of the "Ukrainian School of Mining Engineering - 2019". 
The work of the conference was supported and approved by the management of the coal industry, companies, joint-stock companies, mines, enterprises and institutes. According to the results of the exchange of advanced achievements in technology of mining, participants of the conference unanimously supported the decision to recommend to the mining enterprises and organizations new scientific and technical developments.

\section{Purpose and objectives of the conference}

Today, industry has moved into a new phase 4.0. This transition is facilitated by the development of computer technologies that has increased in pace. Concepts such as artificial intelligence, full automation of processes, virtual and augmented reality, robotics and deserted production are no longer fantasy, this is our present. One of the best places to apply these new technologies is industry, in particular the mining sector. By implementing the latest computer technology to mining enterprises, we will get an unprecedented increase in labor productivity, safety in dangerous conditions for humans, forecasting of technical and economic indicators, etc. In this regard, XIII International research and practice conference "Ukrainian School of Mining Engineering" this year had the main theme "Innovative technologies and intelligent systems in mining".
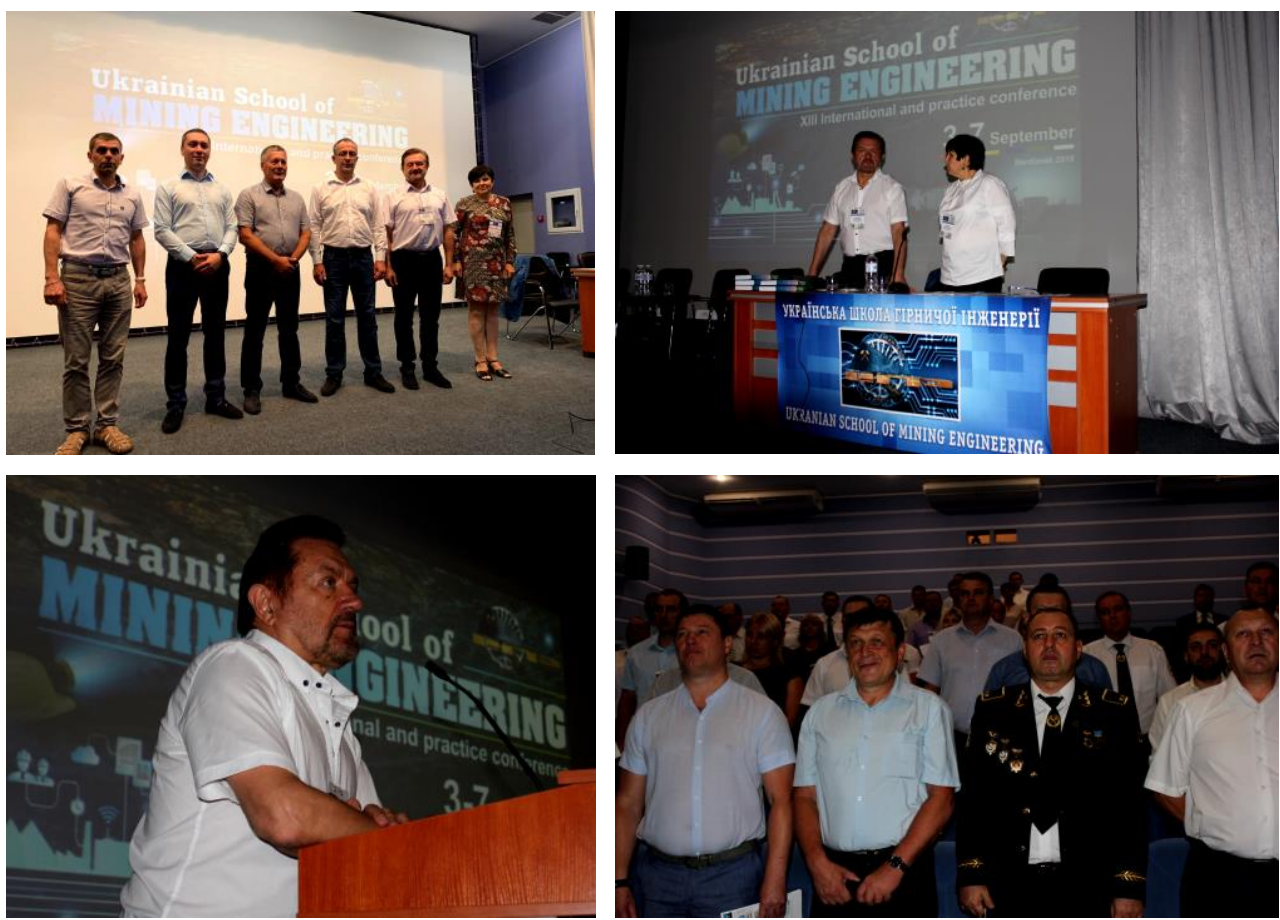

Fig. 2. The conference opening.

Also, the conference did not leave aside many other promising areas of mining engineering. Full list of thematic areas of the conference was the following:

-4.0 industry in mining.

- Augmented and virtual reality.

- Experience of the development of artificial intelligence technologies in mining.

- Digitalization in the mining industry. 3D visualization. Experience of use in mining companies RiO Tinto and Anglo American. 
- The use of virtual copies of planned, current and future states of a mining object based on digital twin technology.

- Mining mechanical engineering.

- Major coal mining trends in the world.

- Alternative energy sources.

- Reuse of mine workings as systems of support and security elements based on geomechanics problems solutions.

- New stoping and tunneling equipment.

- Crisis management in mining.

- The use of geothermal energy of closing mines. Heat pumps.

- Safety of mining, sanitation and labor protection.

- New technologies for mine workings maintaining and supporting.

- Coal mining with maternal ash. Waste rocks backfilling in the mine.

- Auger technology of coal mining from pillars.

- Gas hydrate technology of coalbed methane utilization.

- Domestic and foreign experience of using borehole underground coal gasification.

- The issue of coal enrichment.

- Regulatory requirements for the implementation of rescue operations at mining enterprises.

- Scientific and technical problems of mining of iron, manganese, uranium and other ores.

- Innovative solutions for open pit mining.

Based on the above-mentioned study areas of the conference, the main purpose and objectives become clear. Presentation of the latest achievements in the field of mining engineering, solving acute mining problems, combination of innovative ideas of scientists and researchers with the practical experience of leading mining companies, unification of a community of like-minded people in one network for communication and ideas sharing, development of new areas of the mining business and the development of alternative energy sources, determination of the direction of the industry development vector, all these are the goals that are achieved by conducting the "Ukrainian School of Mining Engineering".

\section{Results and discussion}

This year the "Ukrainian School of Mining Engineering" hosted a large number of people, both residents and foreign colleagues. Scientists and researchers, the enterprise representatives, members of the business community and government, students and postgraduates became the guests of the XIII School. Over the five days of the conference, panel discussions were held with representatives of leading Ukrainian mining companies and a large number of relevant reports were presented.

\subsection{The plenary session}

The work of the conference began with the opening ceremony, where the participants were introduced. Welcoming speeches were made by V. Bondarenko (Head of the Department of Underground Mining of Dnipro University of Technology, Doctor of Technical Sciences, Professor), M. Barabash (Director of the Department of Coal Production of LLC "DTEK Energy", Ph.D.), I. Salyeyev (Chairman of the Board of PJSC "Dnipro Metallurgical Plant") and M. Potapov (CEO of the "Corum Group" Company). Then M. Barabash made the first report "DTEK: A comprehensive approach to decarbonisation" on a very pressing global problem. 


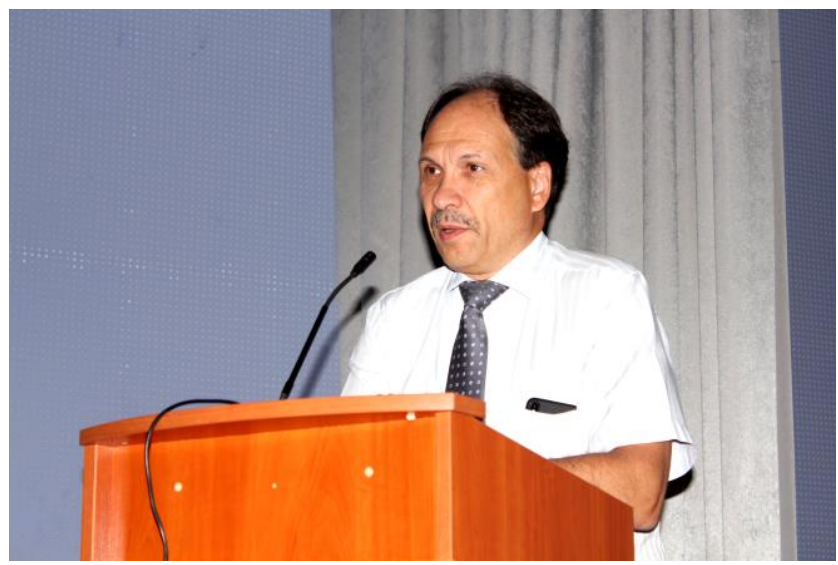

Fig. 3. Report of M. Barabash on decarbonization issue.

Further, after round tables, other conference participants were invited to make their reports. A large number of innovative approaches to solving urgent problems of the mining industry were noted, each report was actively discussed, and the best proposals were adopted.
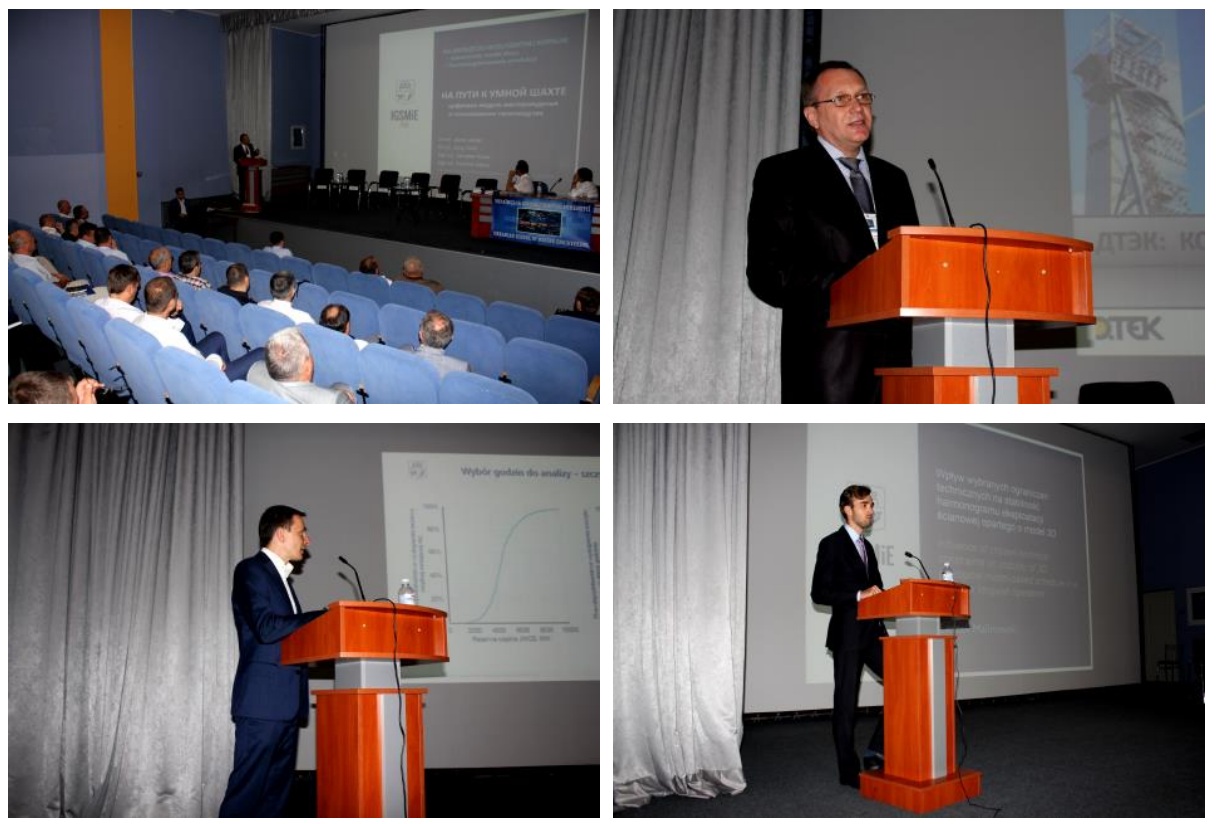

Fig. 4. Reports of participants.

\subsection{The round tables}

On the first day of the conference, after the welcoming speech, two panel discussions were held.

1) Panel discussion "Digital mine copy as a technological and economic business forecast".

The Speaker was V. Bondarenko - Doctor of Technical Sciences, Professor, Head of the Department of Underground Mining of Dnipro University of Technology. As a moderator was M. Shyshov - Head of Technical Development Department of Coal Production Directorate of LLC "DTEK Energy". 


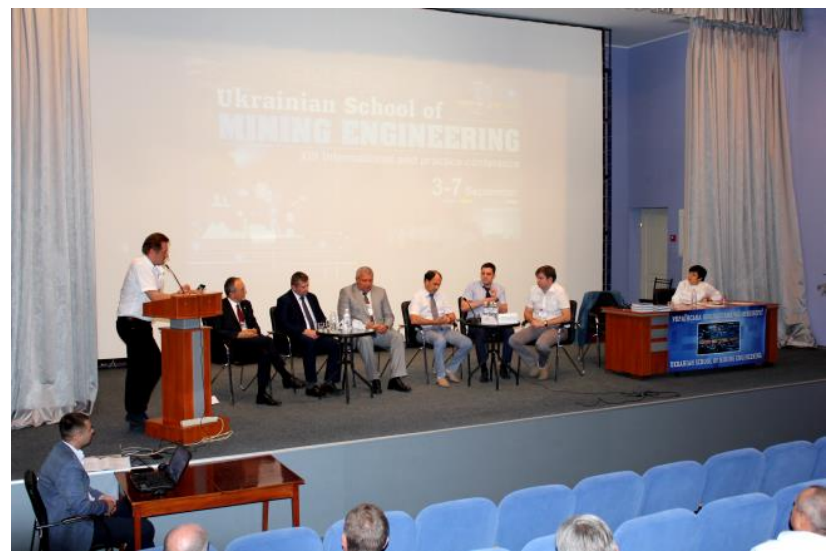

Fig. 5. First panel discussion "Digital mine copy as a technological and economic business forecast".

Panellists of the round table were: M. Barabash - Ph.D., Director of the Department of Coal Production of LLC "DTEK Energy"; V. Chervatiuk - Ph.D., Deputy Director of the Department of Coal Production of LLC "DTEK Energy"; M. Shchurkovski - Chairman of the Board of LLC "Elsta elektronika": J. Kicki - Doctor of Technical Sciences, Professor of Division of Mineral Resource Acquisition of Mineral and Energy Economy Research Institute of the Polish Academy of Sciences; I. Salyeyev - Chairman of the Board of PJSC "Dnipro Metallurgical Plant"; and M. Potapov - CEO of the "Corum Group" Company.

2) Panel discussion "Selective coal mining from very thin coal seams with rocks left in the mined-out longwall space".

The Speaker was D. Malashkevych - Ph.D., assistant of the Department of Underground Mining of Dnipro University of Technology. As a moderator was V. Bondarenko - Doctor of Technical Sciences, Professor, Head of the Department of Underground Mining of Dnipro University of Technology.

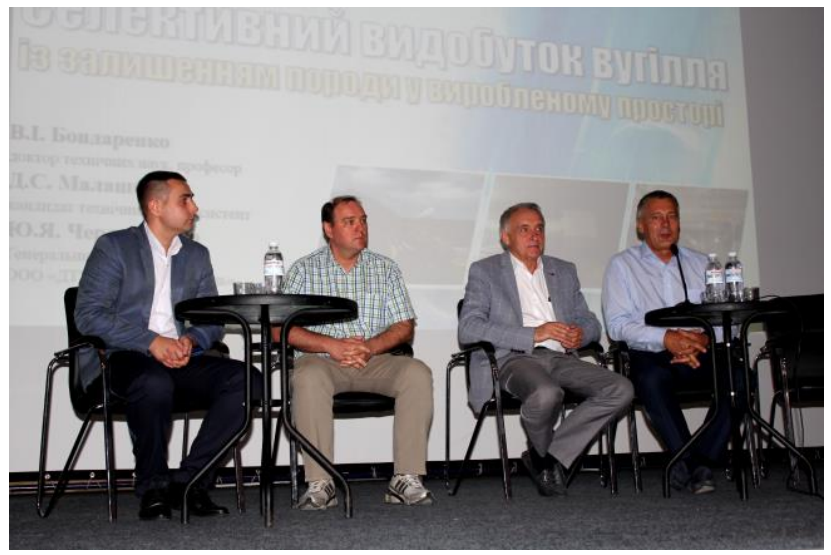

Fig. 6. Second panel discussion "Selective coal mining from very thin coal seams with rocks left in the mined-out longwall space".

Panellists of the round table were Yu. Cherednichenko - CEO of LLC "DTEK Dobropilliavuhillia"; S. Voronon - CEO of PJSC "DTEK Pavlohradvuhillia"; V. Krupytskyi - Director of PJSC "Corum Group - Ukraine"; V. Snihur - Ph.D., Director of MM "Heroiv Kosmosu", PJSC "DTEK Pavlohradvuhillia"; and O. Kovalchuk - CEO of JSC "Svet Shakhtera". 


\subsection{Participants awarding}

The summary of the "Ukrainian School of Mining Engineering" was held at the closing ceremony. By tradition, all new participants of the conference were awarded by commemorative signs as a symbol of belonging to the close-knit community of the School.

All participants presenting reports received certificates for participation in the work of the conference. Also, the following participants were awarded with special diplomas:

- J. Jarosz, member of Mineral and Energy Economy Research Institute of the Polish Academy of Sciences, Division of Mineral Resource Acquisition - for the best conference report;

- O. Yanzhula, Chief Engineer of PJSC "MM Pokrovske" - for the active participation in discussions;

- I. Belykov, First Deputy of the Head of State Paramilitary Mine Rescue Service - for the active participation in discussions;

- E. Frentsel, Chief Technologist of PJSC "MM Ternivske" - for the active participation in the conference.
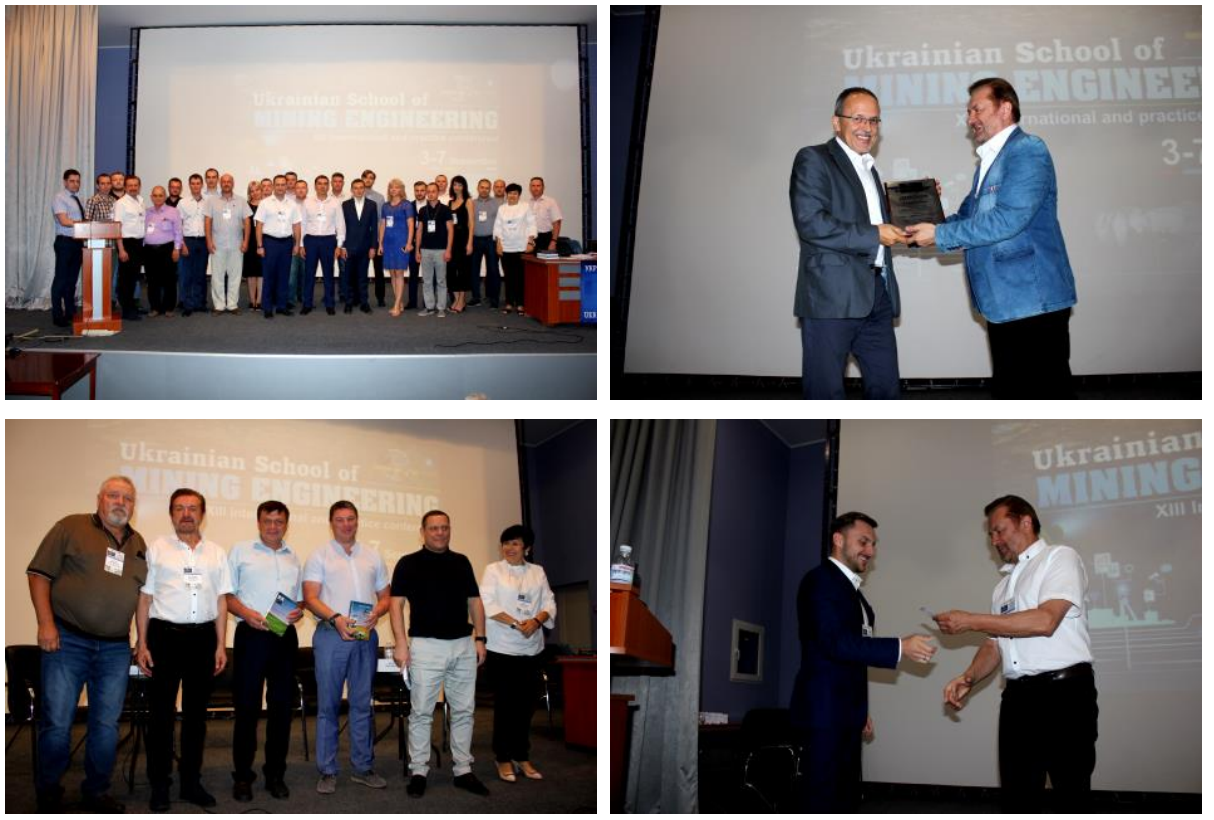

Fig. 7. The closing ceremony.

\section{The resolution}

Representatives of the coal and mining industry of Ukraine, Poland, Russia, China, South Africa and others participated in the conference, made presentations and published scientific materials. Among them: Ministry of Energy and Coal Industry of Ukraine, Ministry of Education and Science of Ukraine, National Academy of Sciences of Ukraine, State Military Mine Rescue Squad of the coal industry of Ukraine, LLC "DTEK Energy", PJSC "DTEK Pavlohradvuhillia", LLC "DTEK Dobropilliavuhillia", LLC "DTEK Research and Design Center", JSC "MM Obukhovskaya" (Russia), LLC "Corum Group”, Dnipro University of Technology, Poltava National Technical Yuri Kondratyuk University, National Technical University "Kharkiv Polytechnic Institute", Kryvyi Rih National University, Institute of Mining Process Physics of NAS of Ukraine, Institute of Geotechnical Mechanics named by 
N. Poljakov of NAS of Ukraine, PJSC "Dnipropetrovsk Aggregate Plant", LLC "Mokrianskyi Stone Quarry No.3", PJSC "Novopoltavskyi Stone Quarry", PJSC "Donetsksteel" metallurgical plant", PJSC "DTEK Zhovtneva CEP", PJSC "DTEK Dobropilska CEP", Branch of "CZF Pavlohradska", LLC "CZF Kurakhivska", State Enterprise "STC Ugleinnovatsiia”, LLC SPE "Standard", LLC "Ukrspetsnaladka", LLC “ANA-TEMS”, LLC "Association of Coal Enterprises", Confederation of Free Trade Unions of Ukraine, Polish Academy of Sciences, Elsta Elektronika Company (Poland).

The resolution of the XIII International Research and Practice Conference "Ukrainian School of Mining Engineering", which is adopted by the participants on September 06, 2019, proclaimed the following.

To express gratitude to the management of LLC "DTEK Energy", PJSC "Donetsksteel" - metallurgical plant", LLC "Corum Group", as well as joint stock companies, enterprises and institutes for supporting the work of the conference and actively participating in the exchange of advanced achievements in technology and advances in mining.

To expand the School's representation by participants that is a leader in advanced mining countries.

To recommend to the mining enterprises and organizations new scientific and technical developments such as:

- Using of the digital twin technology to manage planned, current and future mining operations.

- Technologies for waterproofing the adjacent rocks at the intersection of flooded overlying mine workings.

- Implementation of innovative technologies by Elsta Electronica.

- Technology for dehydration of granular clay carbon-bearing products during the enrichment of coal brand " $G$ ".

- Technologies for the selective transportation of coal and rock, and their separate delivery to the surface.

- Comprehensive service of mining equipment as an important aspect of increasing production efficiency.

- Selective development of complex structural ore deposits by systems with an open stoping zone.

- Implementation of Project management tools in order to optimize the implementation mechanism of mining management solutions.

- Methods of hydrodynamic action on coal seams for combating emissions and gasdynamic phenomena.

- New approaches to the philosophy of conscious industrial safety of mining enterprises.

- Modern design and development planning for mining in coal mines.

- Investigation of financial risks in the extraction of bituminous coal at domestic and foreign mines.

- Ways to improve the work of state-owned enterprises of the coal industry.

- Implementation of support systems of development workings of a new technological level.

- Integrated mining and use of minerals.

- Using the methodology for determining the parameters of the location and supporting of the mine workings, which are overworked during the extraction.

- Using the algorithm for calculating the stress-strain state of the rock mass under the development of formations of shallow coal seams.

- Conducting a joint technical meeting with DTEK in order to discuss the feasibility and possible timing of the implementation of the technology for the selective development of very shallow thin coal seams.

- Aspects of safe production levels during mining of gas-bearing coal seams.

- Improving the efficiency of obtaining geothermal energy from oil wells. 
- Technologies of the multilevel combined support of mine workings carried out in zones of high overburden pressure.

Particular attention was drawn to a panel discussion on the topic "Digital mine copy as a technological and economic business forecast". Panellists: M. Barabash, V. Chervatiuk, M. Shchurkovski, J. Kicki, I. Salyeyev, and M. Potapov. Moderator was V. Bondarenko.

It is recommended that panel discussions be held on the following issues: mining safety, labor protection and sanitation, the implementation of mining equipment, and personal respiratory protection equipment.

To restore in 2020 the work on the preparation of a new edition of "Guidelines for the design and ventilation of coal mines". To ask the State Service of Ukraine on Labor Issues to include the preparation and approval of a new edition of SSSLP 1.1.30-6.09.93 "Guidelines for the design and ventilation of coal mines", approved by order of the State Committee of Ukraine for Supervision of Labor Protection No. 131 from 20.12.1990.

Under the conditions of European integration processes in the field of occupational safety and health, in order to reduce the risks of occupational diseases, to ensure the use of personal protective equipment for respiratory organs and components from one manufacturer in accordance with the requirements of Government Standard EN 529-2006 and the use of reusable filters with $\mathrm{R}$ mark (for any mine labor conditions).

To consider the requirement of paragraph 6.3 .3 of SSSLP 10.0-7.08-93 "Guidelines for the design of ventilation of coal mines", approved by order of the State Supervision Service of Labor Protection of Ukraine dated 20.12.93 No. 131, that the operator of a gas suction plant should disconnect the gas suction installation during the case of a fire occurrence in a mining area, unreasonable and which poses a threat to the life of workers of the site.

To ask the Ministry of Energy and the State Service of Ukraine for Labor Issues to revise as soon as possible the requirement of paragraph 6.3.3 of SSSLP 10.0-7.08-93 "Guidelines for the design of ventilation of coal mines", approved by order of the State Supervision Service of Labor Protection of Ukraine dated 20.12.93 No. 131 regarding the actions of the gas suction unit operator in case of fire in the extraction area.

In order to prevent methane related emergency situations, to recommend for the heads of enterprises:

- to implement additional control of the actual magnitude of methane emission in absolute value, i.e. in $\mathrm{m} 3 / \mathrm{min}$, in mining areas of gas mines, including in areas where complex degassing is carried out, along with existing regulations for monitoring methane concentration;

- to support the operation of methane content control systems in accordance with the technological design documentation for all periods of operation of mining sites. To consider avoiding projects in terms of the methane volume, which is removed during degassing by gas suction units or diluted with air, as an emergency situation with an immediate investigation of the causes of increased methane emissions and the adoption of appropriate measures.

To recommend to the Ministry of Energy and the Coal Industry of Ukraine, and the State Service of Ukraine on Labor Issues during the preparation of a new version of the Safety Regulations for Coal Mines to consider the possibility of including requirements for mandatory monitoring of absolute methane emission from mining sites in real time.

To conduct the XIV International Research and Practice Conference "Ukrainian School of Mining Engineering - 2020" from 1 to 5 of September, 2020.

\section{Conclusions}

The XIII International research and practice conference "Ukrainian School of Mining Engineering", which was held from 3 to 7 of September 2019, is an annual scientific event that has gained good traditions over many years, the reputation of a highly regarded 
scientific platform and publicity among scientists, expert practitioners, active innovators, members of the Ukrainian and international mining community.

The "Ukrainian School of Mining Engineering" is the forefront in mining science because the annual conferences discuss the latest technologies of the modern and near future - virtual and augmented reality, modeling, Big Data, digitization and virtual copies of planned and future objects state based on digital twin technology. The international conference provides an opportunity to look at the future, share best practices with Ukrainian and foreign colleagues, participate in panel discussions, set ambitious goals and invariably achieve them. Large companies of the coal industry always take a leading position in the work of the conference, share their unique achievements in coal mining and draw new sources of inspiration from the reports of scientists and colleagues in production.

The Organizing Committee and scientific editors express their gratitude to the publishing house EDP Sciences (France) and the scientific serial E3S Web of Conferences as a part of EDP Sciences for their prompt assistance in publishing the materials of the XII and XIII International Research and Practice Conference "Ukrainian School of Mining Engineering" and indexing in the international scientific citation database Scopus.

\section{References}

1. Pivnyak, G., Bondarenko, V., \& Kovalevska, I. (2011). Technical and Geoinformational Systems in Mining: School of Underground Mining. The Netherlands, Leiden: CRC Press/Balkema. ISBN: 978-020333266-5; 978-113811244-5.

2. Pivnyak, G., Bondarenko, V., Kovalevska, I., \& Illiashov, M. (2012). Geomechanical Processes During Underground Mining: School of Underground Mining. The Netherlands, Leiden: CRC Press/Balkema. ISBN: 978-020307327-8; 978-041566174-4.

3. Bondarenko, V., Kovalevska, I., \& Ganushevych, K. (2014). Progressive technologies of coal, coalbed methane, and ores mining. The Netherlands, Leiden: CRC Press/Balkema. ISBN: 978-131574031-7; 978-113802699-5.

4. Bondarenko, V., Kovalevska, I., Lysenko, R., Malova, O., Cawood, F., \& Hardygora, M. (Eds.) (2018). Ukrainian School of Mining Engineering. E3S Web of Conferences, (60). Retrieved from https://www.e3s-conferences.org/articles/e3sconf/abs/2018/35/contents/contents.html

5. Underground mining department. Historic outline (2015). Ukraine, Dnipropetrovsk: Litograf. 